\title{
PYROMETALLURGICAL TREATMENT OF SILVER-CONTAINING CATALYSTS
}

\author{
PIROMETALURŠKA OBDELAVA KATALIZATORJA Z \\ VSEBNOSTJO SREBRA
}

\author{
Mária Čarnogurská ${ }^{1}$, Miroslav Př́́hoda ${ }^{2}$, Marián Lázár ${ }^{1}$, Peter Kurilla ${ }^{1}$ \\ 1Technical University of Košice, Faculty of Mechanical Engineering, Košice, Slovakia \\ ${ }^{2}$ VŠB - Technical University of Ostrava, Faculty of Metallurgy and Materials Engineering, Ostrava - Poruba, Czech Republic \\ maria.carnogurska@tuke.sk
}

Prejem rokopisa - received: 2017-05-03; sprejem za objavo - accepted for publication: 2017-08-11

doi:10.17222/mit.2017.050

\begin{abstract}
The following article describes the thermal process for the recovery of used silver from Ag catalysts using an 80-kVA plasma reactor, along with an appropriate flux and reducing agent. An Ag catalyst was melted in three separate experiments with different weights. The overall recovery of silver from the melted Ag catalysts was high (93.8-96.4) \%. The byproducts of the melting of the Ag catalysts were the inert vitrified slag, synthesis gas and fly ash. The chemical analysis of fly ash confirmed that, in addition to mechanically stripped oxides that were present in the batch $\left(\mathrm{CaO}, \mathrm{SiO}_{2}, \mathrm{MgO}\right.$, and $\left.\mathrm{Al}_{2} \mathrm{O}_{3}\right)$, fly ash also contained a high amount of condensed silver. Indeed, silver evaporated at a high temperature during the melting process. The silver condensed in fly ash was at a level of 37.08-48.37\% of the total weight of fly ash. Therefore, fly ash had to be recycled. The synthesis gas from the process had a relatively low heating value $\left(0.6335 \mathrm{MJ} \mathrm{m}^{-3}\right)$.

Keywords: hazardous waste, Ag catalyst, plasma technology
\end{abstract}

Članek opisuje termični način pridobivanja srebra iz rabljenih Ag katalizatorjev v 80 kVA plazemskem reaktorju v prisotnosti ustreznih talil in redukcijskega sredstva. Ag katalizator se je talil v treh poskusih z različno maso. Skupi iznos srebra pri procesu taljenja Ag katalizatorjev je bil visok (od 93,8 \% do 96,4\%). Pri taljenju katalizatorja je nastajala inertna vitrificirana žlindra, sintezni plin in ostale ubežne emisije. Kemična analiza ubežnih emisij je potrdila, da so poleg mehansko odtrganih oksidov iz vhodnega materiala $\left(\mathrm{CaO}, \mathrm{SiO}_{2}, \mathrm{MgO}, \mathrm{Al}_{2} \mathrm{O}_{3}\right)$ vsebovale tudi višjo vsebnost kondenziranega srebra. Srebro je v procesu taljenja izparelo pri visoki temperaturi. V ubežnih emisijah kondenzirano srebro je bilo na nivoju od 37,08 \% do 48,37\%. Ubežne emisije je bilo treba zato reciklirati. S procesom pridobljeni sintezni plin je bil razmeroma nizke kalorične vrednosti $\left(0.6335 \mathrm{MJ} \mathrm{m}^{-3}\right)$.

Ključne besede: nevarni odpadek, Ag katalizator, plazemska tehnologija

\section{INTRODUCTION}

Separation and subsequent recovery of waste is currently of major society-wide importance. Waste often contains secondary raw materials with a relatively high energy and material potential. In many cases, a portion of waste that ends up in landfills or in waste-incineration plants contains valuable components such as non-ferrous and precious metals. With landfilling or conventional waste incineration without an energy recovery, ${ }^{1}$ irreplaceable losses of metals and energy occur, which are accompanied by multiple environmental problems, since there are many different dangerous chemical compounds released, including heavy metals such as mercury, lead, cadmium and others.

Precious metals and also the metals of the platinum group (Pt, $\mathrm{Pd}, \mathrm{Rh}, \mathrm{Ir}$, etc.) are widely used in different industries ranging from the electronics sector (hard disks, multilayer ceramic capacitors, or integrated circuits) to the production of liquid-crystal displays or the chemical industry (catalysts). ${ }^{2}$

\section{DESCRIPTION OF CATALYTIC CONVERTERS}

The development of new catalysts of all types ${ }^{3}$ brings the need for their subsequent recovery, reprocessing and a permanent disposal. Heterogeneous catalysts containing silver are generally used in research and industry as a part of the oxidation, reduction and polymerization processes. A typical example of an application of silverbased catalysts is the ethylene oxide production process. During the catalytic reaction, the oxidation of ethylene into ethylene oxide occurs. This change occurs in the presence of a catalytic Ag layer deposited on an $\mathrm{Al}_{2} \mathrm{O}_{3}$ carrier at a temperature of $220-280{ }^{\circ} \mathrm{C} .{ }^{4-5}$ The composition of the catalyst layer depends on the production method and on the catalyst generator. The silver amount in the majority of these types of catalysts is estimated to be in a range of $8-20 \%$ of mass fractions. The restoration of the properties related to a particular catalyst layer after their depletion is carried out through a regeneration process. The number of regeneration cycles is usually limited by the manufacturer. After the catalyst is exhausted, the material the catalyst was made of is recovered. 


\section{M. ČARNOGURSKÁ et al.: PYROMETALLURGICAL TREATMENT OF SILVER-CONTAINING CATALYSTS}

Recycling of silver and other metals constituting a catalytic layer occurs mainly during a pyrometallurgical, hydrometallurgical or a combined process. ${ }^{6-9}$ A key aspect of the proposal of the recycling process is an accurate determination of the type of the precious metals in the waste, which is subject to a thorough pre-treatment and homogenization.

Specifically, a pyrometallurgical recovery of waste containing precious metals is a waste-reprocessing technology utilizing plasma. High-temperature melting of electronic waste in a plasma reactor is described elsewhere. ${ }^{10}$ In addition to the synthesis gas that is produced during the melting and gasification of electronic waste, and which can be energetically used, there are additional byproducts like alloy metal, inert slag and fly ash. The reduced metal portion and fly ash are used as secondary raw materials for the metallurgical industry, while inert slag, after a modification of its composition, is used in the building sector, for example.

\section{MATERIALS, TECHNOLOGY AND THERMODYNAMIC REFLECTION}

The catalyst used in the chemical industry for the production of ethylene oxide $\left(\mathrm{CH}_{2}(\mathrm{O}) \mathrm{CH}_{2}\right)$ was subjected to the experimental research of melting and gasification. This oxide is an intermediate in the production of ethylene glycol $\left(\mathrm{C}_{2} \mathrm{H}_{4}(\mathrm{OH})_{2}\right)$ and other chemicals. Ethylene oxide finds its use in the health care as an effective sterilizing agent, especially for those materials that could be otherwise damaged due to a high temperature. A relatively small percentage is used for gaseous sterilization of food and cosmetics.

A typical feature of an Ag catalyst is its coloring (gray to gray-green). The catalyst is a non-sticky and powdery product with a grain size below $8 \mathrm{~mm}$. Its composition, indicated by the manufacturer, is represented by two components: $\mathrm{Ag}$ and $\mathrm{Al}_{2} \mathrm{O}_{3}$. One pattern of a used catalyst relating to the quality involves the percentages of the respective oxides, metals, carbon deposits and the moisture. Typical chemical composition of the used Ag catalyst that undergoes an examination and is specified by the manufacturer is described in Table 1 .

Table 1: Typical chemical composition of a catalyst as stated by the waste generator

\begin{tabular}{|l|l|}
\hline \multicolumn{1}{|c|}{ Quality characteristics } & Value $(\%)$ \\
\hline Amount of $\mathrm{Al}_{2} \mathrm{O}_{3}$ & $60.0-85.0$ \\
\hline Amount of $\mathrm{SiO}_{2}$ & $0.50-1.50$ \\
\hline Amount of $\mathrm{MgO}$ & $0.00-0.05$ \\
\hline Amount of $\mathrm{CaO}$ & $0.20-1.00$ \\
\hline Amount of $\mathrm{Fe}_{\text {total }}$ & $0.10-1.50$ \\
\hline Amount of carbon sediments & $0.05-1.00$ \\
\hline Amount of $\mathrm{Ag}$ & $15.0-35.0$ \\
\hline Moisture & $0.05-1.50$ \\
\hline
\end{tabular}

Before the experiment with the plasma melting of the used Ag catalyst was conducted, a chemical analysis was carried out and the results are as follows:

\begin{tabular}{|c|c|c|}
\hline $57.86 \% \mathrm{Al}_{2} \mathrm{O}_{3}$ & $0.22 \% \mathrm{C}$ & $0.19 \% \mathrm{CaO}$ \\
\hline $\begin{array}{c}39.15 \% \mathrm{Ag}_{2} \mathrm{O} \\
(36.45 \% \mathrm{Ag})\end{array}$ & $0.12 \%$ moisture & $0.011 \% \mathrm{MgO}$ \\
\hline $0.95 \% \mathrm{SiO}_{2}$ & $0.12 \% \mathrm{FeO}$ & \\
\hline
\end{tabular}

The total sum of the majority of the components constituting the waste was $98.6 \%$ of mass fractions.

The recovery of precious metals by means of a high-temperature melting process depends on various operating factors, but mainly on the operational processing temperature. If this melting temperature is low, the viscosity of slag is high; moreover, the metals are not able to sediment, and the recovery of precious metals is low.

If the melting point is high, the viscosity of the waste slag is low and the process can result in a high mutual solubility of the liquid phases - the slag and metal. In addition, the slag and metal can leak into the lining of the reactor, increasing the corrosion of the lining itself. At the same time, the volatilization of metals with a low boiling point increases. Nevertheless, the recovery of precious metals can be high.

In order to ensure the maximum recovery of precious metals, it is necessary not only to establish a suitable melting temperature of the catalyst, but also to ensure a composition of the slag that will not cause any corrosion of the lining of the plasma reactor and will have a relatively low viscosity. Table 2 provides the information regarding the melting point, the boiling point and the density of the catalyst component of the Ag catalyst used in this work.

Table 2: Melting point, boiling point and density of $\mathrm{Ag}$ and $\mathrm{Al}_{2} \mathrm{O}_{3}{ }^{13}$

\begin{tabular}{|c|c|c|c|c|}
\hline \multirow{2}{*}{ Component } & $\begin{array}{c}\text { Melting } \\
\text { point }\end{array}$ & $\begin{array}{c}\text { Boiling } \\
\text { point }\end{array}$ & \multicolumn{2}{|c|}{ Density $\left(\mathrm{kg} \mathrm{dm}^{-3}\right)$} \\
\cline { 2 - 5 } & $\left({ }^{\circ} \mathrm{C}\right)$ & $\left({ }^{\circ} \mathrm{C}\right)$ & $20{ }^{\circ} \mathrm{C}_{(\mathrm{s})}$ & $960.8{ }^{\circ} \mathrm{C}_{(\mathrm{l})}$ \\
\hline $\mathrm{Ag}$ & 960.8 & 2161 & 10.49 & 9.32 \\
\hline $\mathrm{Al}_{2} \mathrm{O}_{3}$ & 2050.8 & 2999 & 3.95 & - \\
\hline
\end{tabular}

During the melting of the Ag catalyst, there is a need to take into consideration the dependence of the saturated pressure $p$ on the temperature $T$. The reference value for this dependence can be determined in Equation (1) according to the expression from: ${ }^{11}$

$$
\begin{gathered}
\lg p=-14400 \cdot T^{-1}-0.85 \cdot \lg T+13.8249 \\
<(1233-2434) \mathrm{K}>
\end{gathered}
$$

A previously published paper $^{12}$ states that silver oxide is formed due to chemical reaction in Equation (2):

$$
4 \mathrm{Ag}_{(\mathrm{s})}+\mathrm{O}_{2(\mathrm{~g})}=2 \mathrm{Ag}_{2} \mathrm{O}_{(\mathrm{s})}
$$

During the reaction, the standard change in the Gibbs free energy is expressed as follows in Equation (3):

$$
\Delta G_{\mathrm{T}}^{0}=-56260+121.31 \cdot T<(298-1000) \mathrm{K}>
$$


Up to a temperature of $191^{\circ} \mathrm{C}$, the silver oxide is stable. The solubility of oxygen in molten silver is described $^{13}$ with the following reaction in Equation (4):

$$
1 / 2 \mathrm{O}_{2}=[\mathrm{O}]_{\mathrm{Ag}(1)}
$$

The standard change in the Gibbs free energy in this case is

$$
\Delta G_{\mathrm{T}}^{0}=-10460+18.03 \cdot T
$$

For the solubility of hydrogen in molten silver, the Sieverts law applies. There is an interaction between the gas and the liquid phase according to the following reactions:

$$
\begin{gathered}
\mathrm{H}_{2}=2[\mathrm{H}]_{\mathrm{Ag}(1)} \\
{[\mathrm{H}]_{\mathrm{Ag}(1)}=\mathrm{A} \cdot \sqrt{p_{\mathrm{H}_{2}}}}
\end{gathered}
$$

The dependence of the solubility of silver atoms on the temperature at a hydrogen pressure of $101.325 \mathrm{kPa}$ is shown in Figure 1. ${ }^{13}$

During the melting experiment, an appropriate melting agent should be added, so that it forms, with the aluminum oxide, a slag with a low melting point and low viscosity. The choice of the additive is based on the understanding that there is a significant difference between the melting temperature of the $\mathrm{Ag}$ catalyst and the melting temperature of silver alumina. It is requested as well that the amount of $\mathrm{SiO}_{2}$ in the melted slag does not exceed the limit of 3-5\% so that the slag can be eventually reused, if possible, in the steel industry, for example. The melting agent that meets these requirements is $\mathrm{CaO}$.

The amount of recovered metal from the melting process depends on the chemical reactions taking place in the reaction chamber of a plasma reactor. At constant

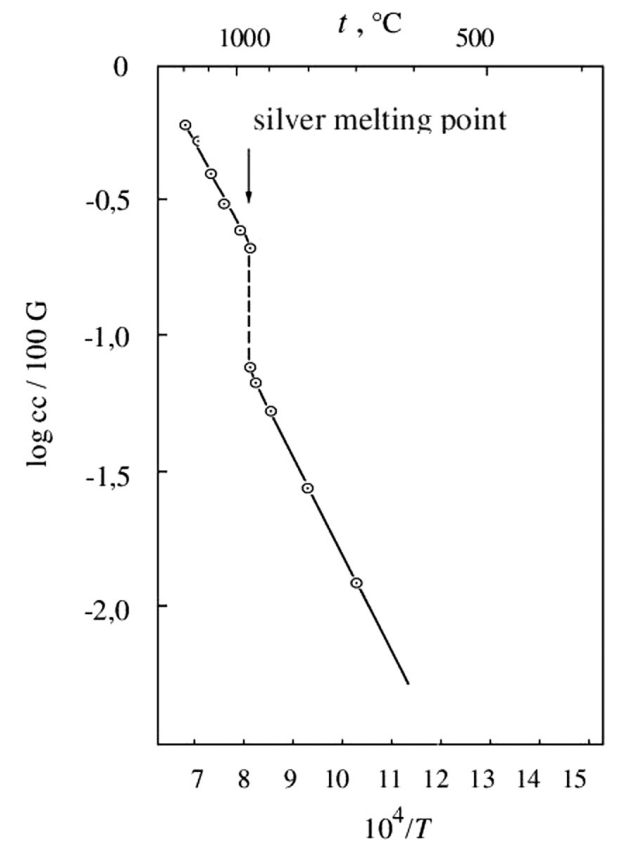

Figure 1: Solubility dependence of hydrogen in silver pressure and temperature, the reactions can be described with the standard change in the Gibbs free energy for the reduction of metal oxides. Based on the diagram of the stability of the phases in the system $\mathrm{Cu}-\mathrm{Fe}-\mathrm{Ni}-\mathrm{Sn}-\mathrm{Zn}$ $\mathrm{Cd}-\mathrm{Pb}-\mathrm{O}$, the reaction is discussed in detail elsewhere. ${ }^{8}$ The optimal melting and gasification temperature of the given waste was found to be $1400{ }^{\circ} \mathrm{C}$. The melting temperature of silver is $960.8{ }^{\circ} \mathrm{C}$ and that of alumina is $2050.8{ }^{\circ} \mathrm{C}$. In order to reduce the melting point, an additional melting agent is needed in the batch. Suitable fluxing agents are fluorspar $\left(\mathrm{CaF}_{2}\right)$ and anhydrous borax $\left(\mathrm{Na}_{2} \mathrm{~B}_{4} \mathrm{O}_{7}\right)$. To provide a reducing atmosphere in the reactor, it is necessary to add a reducing agent to the batch. This agent also serves to reduce the amount of water that is present in the reactor in the form of humidity. The reduction of the water vapor takes place according to reaction in Equation (8). The Equation shows that, for $1 \mathrm{~kg}$ of moisture, $0.67 \mathrm{~kg}$ of $\mathrm{C}$ should be added.

$$
\mathrm{C}+\mathrm{H}_{2} \mathrm{O} \rightarrow \mathrm{CO}+\mathrm{H}_{2}
$$

The quantity of the reducing agent added to the batch is usually about $20 \%$ higher than the amount that is calculated theoretically. This amount, added to the plasma reactor, provides a sufficient quantity of the reducing agent for an eventual oxygen reduction. Indeed, oxygen enters the melting process in the reactor and can cause an oxidation of the graphite hearth. A sufficient amount of the reducing agent in a plasma reactor is needed to protect the graphite hearth against the oxidation. At the same time, strong reducing conditions occur in the reactor. These particular conditions induce an increase of carbon monoxide in the synthesis gas and reduce the proportion of carbon dioxide.

\section{MELTING OF SILVER-BASED CATALYSTS IN A PLASMA REACTOR}

The composition of the waste was selected, prior to the melting, in such a way that the emerging slag had a relatively low melting point (below $1400{ }^{\circ} \mathrm{C}$ ). At the same time, and at a given temperature, the final slag had to be saturated with a compound of the type $\mathrm{xCaO} \cdot \mathrm{yAl}_{2} \mathrm{O}_{3}$, or pure alumina, thus avoiding the corrosion of the lining that contains a high amount of $\mathrm{Al}_{2} \mathrm{O}_{3}$. In addition, after a partial corrosion of the lining, the temperature in the plasma reactor stabilized and, at the level of this stabilized temperature, a solidified slag layer was created on the inner surface of the lining. This layer protected it from further corrosion.

The experiment was carried out in an 80-kVA plasma reactor with a hollow graphite electrode. The plasma gas was nitrogen. In Table 3, there is a description of the starting materials, which constituted the charge, along with the other parameters characterizing the melting process. The Ag catalyst was melted in three separate experiments with various weights. 


\section{M. ČARNOGURSKÁ et al.: PYROMETALLURGICAL TREATMENT OF SILVER-CONTAINING CATALYSTS}

The melted alloy that resulted from each experiment was subjected to a chemical analysis. The results of the analysis show that, in addition to silver, the alloy contains iron particles. The resulting alloy was further refined with electrolysis. The amount of the alloy obtained during the melting of $100-123 \mathrm{~kg}$ of the catalyst ranged from $34.94 \mathrm{~kg}$ to $42.15 \mathrm{~kg}$ (Table 4). The total recovery of silver from the melting of the Ag catalyst in the plasma reactor was high (ranging from $93.8 \%$ to $96.4 \%$ ) (Table 4). The chemical composition of the slag from the melting and gasification of the Ag catalyst is described in Table 5. All the elements with a high affinity to oxygen, including, in particular $\mathrm{Al}, \mathrm{Si}, \mathrm{Mg}$ and Ca became part of the slag along with a small portion of iron in the form of FeO. The slag contained only stripped and non-sedimented droplets of $\mathrm{Ag}$ as documented on the macro-picture of the fractured surface of the slag in Figure 2. The quantity of silver in the slag determines the type of slag (dump or returned slag) that must be treated again. Based on the requirements for the recovery of silver, the silver content in the dump slag should not exceed the limit of $0.5 \%$ of Ag. Both types of slag were subjected to a leaching test. The chemical composition of the fly ash, generated during the gasification and melting of the Ag catalyst, which was collected around the area of the synthesis-gas purification, is shown in Table 6.

Table 3: Basic data of the raw material

\begin{tabular}{|c|c|c|c|c|c|c|}
\hline 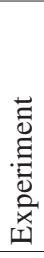 & 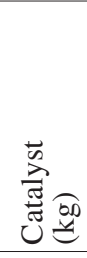 & 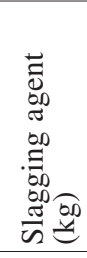 & 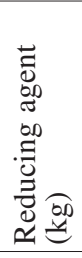 & 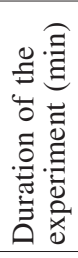 & 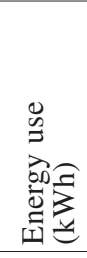 & 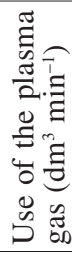 \\
\hline 1 & 100.0 & 68.45 & 0.50 & 405 & 74.15 & 8.5 \\
\hline 2 & 100.0 & 68.80 & 1.00 & 445 & 70.31 & 8.5 \\
\hline 3 & 123.0 & 84.20 & 1.50 & 510 & 66.30 & 8.5 \\
\hline
\end{tabular}

$\mathrm{dm}^{3}$ - volume of gas media at the pressure of $p=101.325 \mathrm{kPa}$ and temperature of $25{ }^{\circ} \mathrm{C}$

Table 4: Alloy - mass and chemical composition

\begin{tabular}{|c|c|c|c|c|c|c|}
\hline \multirow{2}{*}{$\begin{array}{c}\text { Experi- } \\
\text { ment }\end{array}$} & Alloy & \multicolumn{5}{|c|}{ Chemical composition (\%) } \\
\hline & $\underset{(\mathrm{kg})}{\mathrm{Ag} \text { alloy }}$ & $\mathrm{Ag}$ & $\mathrm{Fe}$ & $\mathrm{Al}$ & $\mathrm{Si}$ & $\mathrm{Cu}$ \\
\hline 1 & 34.94 & 99.40 & 0,72 & 0.04 & 0.02 & 0.00 \\
\hline 2 & 35.21 & 99.78 & 0.20 & 0.02 & 0.00 & 0.00 \\
\hline 3 & 42.15 & 99.80 & 0.15 & 0.05 & 0.00 & 0.00 \\
\hline
\end{tabular}

Table 5: Slag - mass and chemical composition

\begin{tabular}{|c|c|c|c|c|c|c|c|}
\hline \multirow{2}{*}{$\begin{array}{c}\text { Experi } \\
\text { ment }\end{array}$} & $\begin{array}{c}\text { Dump } \\
\text { slag }\end{array}$ & \multicolumn{6}{|c|}{ Chemical composition (\%) } \\
\cline { 2 - 8 } & $\begin{array}{c}\text { Slag } \\
(\mathrm{kg})\end{array}$ & $\mathrm{CaO}$ & $\mathrm{MgO}$ & $\mathrm{SiO}_{2}$ & $\mathrm{Al}_{2} \mathrm{O}_{3}$ & $\mathrm{Ag}_{\text {total }}$ & $\mathrm{Fe}_{\text {total }}$ \\
\hline 1 & 129.50 & 46.72 & 0.05 & 1.05 & 52.46 & 0.017 & 0.11 \\
\hline 2 & 126.00 & 45.05 & 0.05 & 0.93 & 53.10 & 0.021 & 0.07 \\
\hline 3 & 159.50 & 47.84 & 0.04 & 1.08 & 51.02 & 0.038 & 0.10 \\
\hline
\end{tabular}

The energy of the synthesis gas, which was produced during the melting of the $\mathrm{Ag}$ catalyst and subsequently purified, was used in a cogeneration unit with a microturbine CAPSTONE C65. The rates of the average concentrations of the main constituents of synthesis-gas components $\left(\mathrm{CO}, \mathrm{CO}_{2}, \mathrm{H}_{2}, \mathrm{~N}_{2}\right.$ and $\left.\mathrm{CH}_{4}\right)$ obtained with continuous chromatographic measurements, are shown in Table 7.

Table 6: Fly ash - mass and chemical composition of the main components

\begin{tabular}{|c|c|c|c|c|c|c|c|}
\hline $\begin{array}{c}\text { Experi- } \\
\text { ment }\end{array}$ & $\begin{array}{c}\text { Fly ash } \\
(\mathrm{kg})\end{array}$ & $\mathrm{CaO}$ & $\mathrm{MgO}$ & $\mathrm{SiO}_{2}$ & $\mathrm{Al}_{2} \mathrm{O}_{3}$ & $\mathrm{Ag}_{\text {total }}$ & $\mathrm{Fe}_{\text {total }}$ \\
\hline 1 & 2.5 & 15.15 & 0.02 & 0.30 & 23.74 & 43.45 & 1.12 \\
\hline 2 & 2.0 & 15.77 & 0.02 & 0.51 & 25.99 & 37.08 & 0.90 \\
\hline 3 & 4.1 & 17.60 & 0.01 & 0.22 & 22.17 & 48.37 & 0.84 \\
\hline
\end{tabular}

Table 7: Syngas and average values of the components

\begin{tabular}{|c|c|c|c|c|c|c|}
\hline \multirow{2}{*}{$\begin{array}{c}\text { Experi- } \\
\text { ment }\end{array}$} & \multirow{2}{*}{$\begin{array}{c}\text { Syngas } \\
\left(\mathrm{m}^{3} \mathrm{~h}^{-1}\right)\end{array}$} & \multicolumn{5}{|c|}{$(\mathrm{vol} \%)$} \\
\cline { 3 - 7 } & $\mathrm{H}_{2}$ & $\mathrm{CO}$ & $\mathrm{CO}_{2}$ & $\mathrm{CH}_{4}$ & $\mathrm{~N}_{2}$ \\
\hline 1 & 10.70 & 3.03 & 2.30 & 1.16 & 0.00 & 93.51 \\
\hline 2 & 12.45 & 1.87 & 1.27 & 1.07 & 0.00 & 95.79 \\
\hline 3 & 12.30 & 2.68 & 2.12 & 1.31 & 0.00 & 93.89 \\
\hline
\end{tabular}

$\mathrm{m}^{3}$ - volume of gas media at the pressure of $p=101.325 \mathrm{kPa}$ and temperature of $25^{\circ} \mathrm{C}$

\section{DISCUSSION}

The plasma melting and gasification of the used Ag catalyst in the 80-kVA plasma reactor can be evaluated as follows in terms of material and energy use of the waste.

Silver losses occurred due to the evaporation and the subsequent condensation in the fly ash as well as due to the tapping of the metal alloy with the slag phase, i.e., a deficient sedimentation of silver at the bottom of the reactor. Throughout the continuous tapping of the slag during the waste-melting process, very fine particles of silver were pulled in the dump slag due to the flow of the

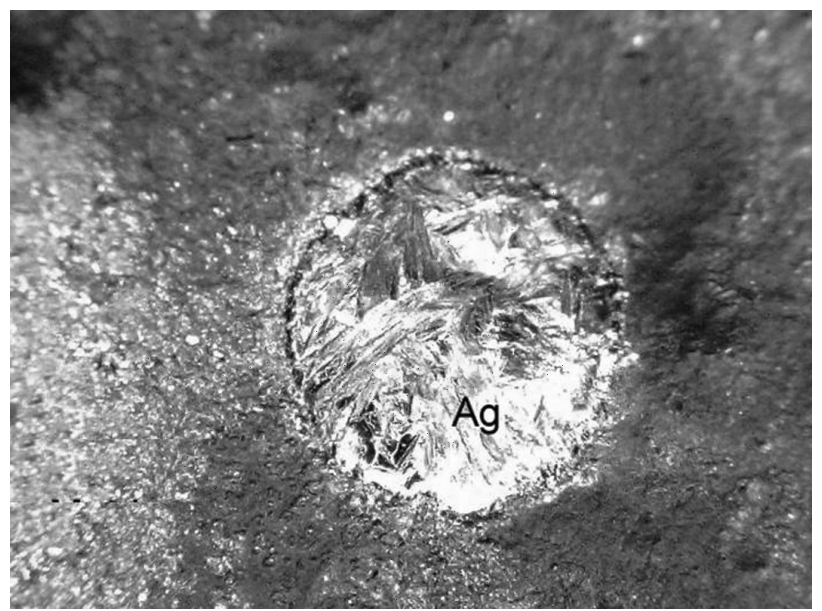

Figure 2: Macro photography of a mechanically trapped silver ball in the slag matrix 


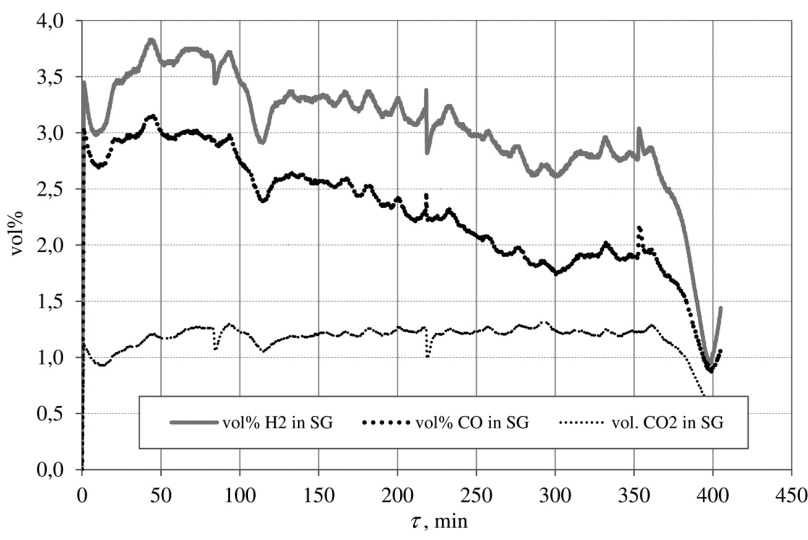

Figure 3: Change in the syngas composition during the first experiment

slag itself. This loss of metal can be considered as the total loss of Ag during the plasma-melting process because the other loss of silver from the fly ash and from the reusable slag can be eliminated with repeated melting. A reversible Ag loss is the loss into the lining of the reactor that becomes saturated with silver during the first melting processes due to the diffusion of silver and the leaking between the segments of the lining.

The thermodynamic analysis of the melting and gasification of the Ag catalyst and fluxes show that throughout the treatment, besides the vitrified slag, there were also synthesis gas and fly ash. In a strong reducing atmosphere, all the compounds with a high affinity to oxygen, which mainly include $\mathrm{Al}_{2} \mathrm{O}_{3}, \mathrm{SiO}_{2}, \mathrm{MgO}$ and $\mathrm{CaO}$, form an inert slag. Inert slag with a silicate structure concentrates as a separate liquid phase above the surface of the metal. The part of the iron that is found in the slag in the form of $\mathrm{FeO}$ creates, together with silver, a metal phase - an alloy, concentrated at the bottom of the reactor. The liquid phases - the slag and alloy - are periodically tapped from the reactor during the melting. The leaching tests show that calcium is extracted from the slag. However, this does not interfere with a further effective use of the slag in the process of ferrous metallurgy.

The chemical analysis of the obtained fly ash shows that, in addition to the oxides that were mechanically stripped from the batch $\left(\mathrm{CaO}, \mathrm{SiO}_{2}, \mathrm{MgO}\right.$, and $\left.\mathrm{Al}_{2} \mathrm{O}_{3}\right)$, the ash contained a high quantity of the condensed silver that evaporated at a high temperature during the melting and gasification of the Ag catalyst. The amount of silver in the fly ash ranges from $37.08 \%$ to $48.37 \%$. Therefore, the fly ash needs to be recycled.

The synthesis gas, arising from a strongly reducing condition, has a higher quantity of $\mathrm{CO}$ than $\mathrm{CO}_{2}$. The gas, generated throughout the melting of the $\mathrm{Ag}$ catalyst with a high-temperature pyrolysis decomposition of the organic raw material, was discharged from the plasma reactor through a cyclone separator. The majority of the mechanically stripped fly ash particles were collected in the cyclone. Subsequently, the synthesis gas was rapidly

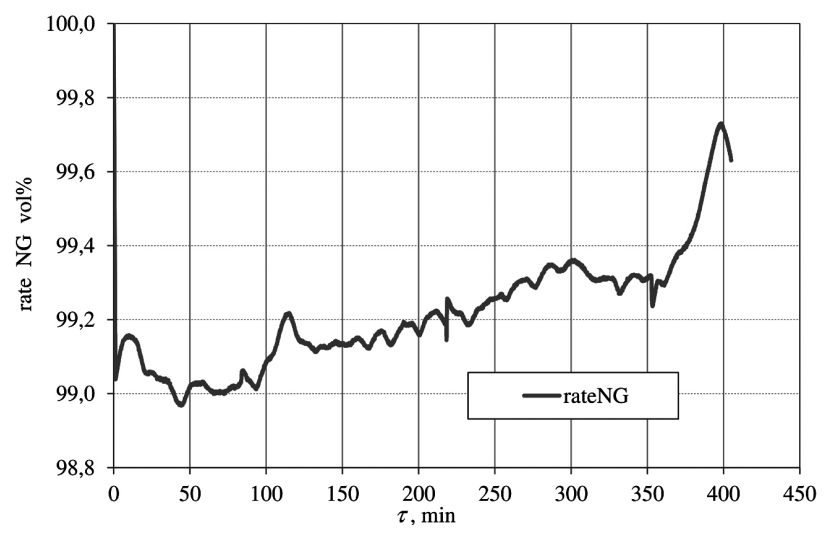

Figure 4: Proportion of natural gas in the mixture with syngas during the first experiment

cooled from a temperature of $1500-1600{ }^{\circ} \mathrm{C}$ to $160-170{ }^{\circ} \mathrm{C}$ in a hydrocyclone. In such a way, the rest of the Ag microparticles were captured in a bag filter. In the next step, the acidic components of the synthesis gas were neutralized in a countercurrent absorption column using $\mathrm{NaOH}$ with $\mathrm{pH}=9$. From the absorption column, the synthesis gas was led into the cooling system, where, in the first step, it was cooled below the dew point of $60{ }^{\circ} \mathrm{C}$. The moisture, which entered the gas during the cooling in the hydrocyclone and neutralization in the countercurrent absorption column, was condensed. After the cooling, the purified synthesis gas was heated above the dew point temperature and then burned in a cogeneration unit with a micro-turbine CAPSTONE C65.

Figure 3 indicates the composition of the synthesis gas produced during experiment no. 1 at the steady-state batch feeding. The syngas was then used in an energy co-generation unit. The synthesis gas had a very low heating value. The mean value was $0.6335 \mathrm{MJ} \mathrm{m}^{-3}$. For an amount of the combusted syngas equal to $10.7 \mathrm{~m}^{3} \mathrm{~h}^{-1}$ (Table 7) and the given heating value of $0.6335 \mathrm{MJ} \mathrm{m}^{-3}$, the energy contribution of the syngas was negligible (Figure 4). The energy contained in the synthesis gas was on average only $0.076 \%$ of the total energy contained in the consumed natural gas. Nevertheless, it is useful to use syngas in the process.

\section{CONCLUSION}

Negative environmental impact of used Ag catalysts can be avoided with their melting and gasification in a plasma reactor. Indeed, three main products can be obtained in the melting process: a silver alloy, syngas and synthetic slag that is useable also in the metallurgy of iron and steel. A sign accompanying the melting of an $\mathrm{Ag}$ catalyst is the formation of fly ash in the synthesis gas, which, in addition to the stripped oxides of calcium, magnesium, silicon and aluminum, contains condensed silver. Fly ash must be therefore recycled and the amount of silver obtained with the melting of the catalysts 


\section{M. ČARNOGURSKÁ et al.: PYROMETALLURGICAL TREATMENT OF SILVER-CONTAINING CATALYSTS}

increases. The synthesis gas has energy parameters that allow its use in the production of heat and electricity. ${ }^{14-15}$

Based on the results presented in this study, concerning the melting of an $\mathrm{Ag}$ catalyst, it can be concluded that such a hazardous waste can be transformed into an inert product using the plasma technology, and the products of the melting can be subsequently used. Therefore, the process of liquefaction of the analyzed waste can be considered as the BAT (best available technology).

\section{Acknowledgments}

The paper was supported by grant agencies KEGA, no. 003TUKE-4/2016, and SP2017/37-FMMI VŠB TUO.

\section{Nomenclature}

A - constant $/ 1$

$\Delta G_{\mathrm{T}}^{0}-$ standard change in Gibbs free energy $/ \mathrm{J} \mathrm{mol}^{-1}$

$[\mathrm{H}]_{\mathrm{Ag}(\mathrm{l})}-$ hydrogen concentration in melted $\mathrm{Ag}$ $/ \mathrm{cm}^{3} / 100 \mathrm{~g}$

$[\mathrm{O}]_{\mathrm{Ag}(\mathrm{l})}$ - oxygen concentration in melted $\mathrm{Ag} / \mathrm{cm}^{3} / 100 \mathrm{~g}$ $p_{\mathrm{H}_{2}}-$ partial pressure of oxygen in the atmosphere $/ \mathrm{Pa}$ $T$ - temperature /K

\section{REFERENCES}

${ }^{1}$ J. Vlček, M. Velička, D. Jančar, J. Burda, V. Blahůšková, Modelling of thermal processes at waste incineration, Energy Sources, Part A: Recovery, Utilization and Environmental Effects, 38 (2016) 23, 3527-3533, doi:10.1080/15567036.2016.1161680
${ }^{2}$ A. Fornalczyk, Industrial catalysts as a source of valuable metals, JAMME, 55 (2012), 864-869

${ }^{3}$ V. Nikolić, B. Agarski, Ž. Kamberović, Z. Andić, I. Budak, B. Kosec, Multi-criteria analysis of synthesis methods for Ni-based catalysts, Mater. Technol., 50 (2016) 4, 553-558, doi:10.17222/ mit.2015.147

${ }^{4}$ P. Kurilla, Dissertation work. TUKE, Košice, (2012). (In Slovak)

${ }^{5} \mathrm{~W}$. C. Cooper, The treatment of copper refinery anode slimes, IOM,42 (1990) 8, 45-49, doi:10.1007/BF03221054

${ }^{6}$ J. Hait, R. K. Jana, S. K. Sanyal, Processing of copper electrorefining anode slime: a review, Mineral Processing and Extractive Metallurgy, Transactions of the Institutions of Mining and Metallurgy: Section C, 118 (2009) 4, 240-252, doi:10.1179/174328509X431463

${ }^{7}$ O. Kubaschewski, C. B. Alcock, Metallurgica Thermochemistry, Fifth Edition, Pergamon Press, Oxford 1979, p. 126

${ }^{8}$ I. Imriš, M. Skoršepa, T. Laco, Extraction of Selenium and Silver from Anode Slime by Roasting and Smelting, Pyrometallurgy, 95, 1995, IMM Cambridge, 157-165

${ }^{9}$ H. E. Hilliard, Silver Recycling in the United States in 2000, Reston Virginia, 2003

${ }^{10}$ M. Lázár, I. Imriš, M. Lázárová, P. Horbaj, Chem. Listy, 109 (2015), 543-549

${ }^{11}$ L. Komorová, I. Imriš, Termodynamika v hutníctve, Alfa, Bratislava 1991

${ }^{12}$ A. Luraschi, J. F. Elliot, Kinetics of oxide formation in liquid copper and silver, Metallurgical and Material Transactions B, 6 (1975) 1, doi:10.1007/BF02825679

${ }^{13}$ T. Bagshaw, A. Mitchell, Solubility of Hydrogen in Liquid Silver, Transactions of the Metallurgical Society of AIME, 242 (1968), 343

${ }^{14}$ R. Nosek, M. Holubčik, Š. Papučík, Emission Controls Using Different Temperatures of Combustion Air, The Scientific World Journal, 2014, doi:10.1155/2014/487549

${ }^{15}$ P. Vician, M. Holubčík, J. Palacka, J. Jandačka, Impact of various operating modes on performance and emission parameters of small heat source, AIP Conference Proceedings 1745, 020065 (2016), doi: $10.1063 / 1.4953759$ 